\title{
A Global Perspective on the Management of Bacterial Infections in Pregnancy: A Systematic Review of International Guidelines
}

\author{
Michal Koucky \\ Univerzita Karlova 1 lekarska fakulta \\ Rasha Kamel \\ Cairo University Kasr Alainy Faculty of Medicine

\section{Lucie Vistejnova} \\ Univerzita Karlova Lekarska fakulta v Plzni \\ Vladimir Kalis \\ Univerzita Karlova Lekarska fakulta v Plzni \\ Khaled M.K. Ismail ( $\sim$ khaled.ismail@lfp.cuni.cz ) \\ Univerzita Karlova Lekarska fakulta v Plzni https://orcid.org/0000-0001-9449-0706
}

\section{Research article}

Keywords: Antibiotics, Antimicrobials, Chorioamnionitis, Concordance, Discordance, Evidence, GBS, Interventions, intra-amniotic, Pregnancy, PRISMA, PROM, Sepsis, Streptococcal

Posted Date: August 10th, 2020

DOI: https://doi.org/10.21203/rs.3.rs-50216/v1

License: (c) (i) This work is licensed under a Creative Commons Attribution 4.0 International License. Read Full License

Version of Record: A version of this preprint was published at The Journal of Maternal-Fetal \& Neonatal Medicine on October 28th, 2020. See the published version at https://doi.org/10.1080/14767058.2020.1839879. 


\section{Abstract}

Introduction: Maternal sepsis is a leading cause of maternal and neonatal mortality. Despite the availability of management protocols, there is disparity in case fatality rates for pregnancy-related sepsis compared to other maternity-related complications. The main aim of this systematic review was to assess concordance between international evidence-based guidelines for the prevention and management of childbirth-related bacterial infections.

Material and methods: The PRISMA statement was followed during the conduct and reporting of this review. PubMed and G-I-N were searched electronically from 2009 to November 2019 for clinical guidelines covering the topic of childbirth-related infections and specific searches for relevant guidelines on the websites of the top 5 international professional bodies most commonly identified by our searches. We did not apply any language restrictions. Guidelines were included if they provided any information about the prevention or management of childbirth-related bacterial infections irrespective of whether the guideline stated a recommendation or not. Two independent reviewers undertook study selection, decisions about inclusion of selected guidelines and data extraction. Extracted information was synthesized under the following topics: Asymptomatic bacteriuria; group $B$ streptococcal infection (GBS); preterm premature rupture of membranes (P-PROM); Intrauterine infection; Interventions and procedures; maternal sepsis; miscellaneous. Concordance was defined as absence of contradictory information between the different guidelines with regards to a specific topic, subtopic or recommendation. Quality of included guidelines was assessed against the AGREE II guideline reporting domains.

Results: A total of 43 guidelines were selected of which 11 were excluded leaving 32 guidelines that fulfilled our inclusion criteria. None of the guidelines fulfilled all the quality assessment domains and 11 (34\%) of the guidelines satisfied 1 - 2 of domains only. Two guidelines covered the topic of asymptomatic bacteriuria, nine for GBS, five for P-PROM and three covered each of intra-amniotic infections maternal sepsis, obstetric procedures and interventions topics. The remaining guidelines covered miscellaneous topics.

Conclusions: There was concordance between guidelines with regards to several aspects in the prophylaxis and treatment of bacteriological infections in pregnancy. Nevertheless, there were several areas of discordance, some of which reached the extent of contradictory information as in the case of antenatal screening for GBS.

\section{Introduction}

Pregnancy and childbirth are associated with several physiological changes, both immunological and mechanical, that increase the susceptibility of the mother and baby to infection. Moreover, there are several conditions associated with pregnancy and childbirth that can act as the primary focus for such an infection like Group B streptococcal (GBS) colonization, Premature rupture of membranes (PROM) or urinary tract and wound infections. Childbirth-related infections have been associated with several problems at the long term, including, chronic pelvic pain, subfertility, ectopic pregnancy and consequences of defective mother-child bonding. Pregnancy-related infections are also one of the leading causes of maternal and neonatal death globally [1-4]. The WHO Global Maternal Sepsis Study (GLOSS) Research Group has recently reported that Infection-related maternal deaths contributed to more than half of the intra-hospital deaths identified during their study period [5]. Although the prevalence of sepsis-related maternal mortality is much higher in low and middle-income countries (LMICs), sepsis in pregnancy is still one of the most important causes of maternal death in the developed world as well [6]. 
There is disparity in case fatality rates for pregnancy-related sepsis compared to other maternity-related complications. Despite the availability of management protocols, coverage of evidence-based interventions for preventing and treating maternal infectious morbidities is generally suboptimal and varies largely within and across countries. Systematically developed clinical practice guidelines are the foundation based on which healthcare providers plan their management, patients make their choices and regulators set their standards [7]. Given the finite resources from which guidelines can be developed, the standardized methodology for developing them and the clinical importance of perinatal sepsis; one would expect consistency between different evidencebased guidelines covering this topic. Therefore, we hypothesized that there would be no discordance in recommendations between evidence-based guidelines for the prevention and management of childbirth-related bacterial infections developed by different authorities and the objective of this systematic review was to test this hypothesis.

\section{Methods}

\section{Eligibility criteria, information sources \& search strategy:}

The PRISMA statement and checklist were followed during the conduct and for the reporting of this review [8]. PubMed was searched electronically from 2009 to November 2019 for clinical guidelines covering the topic of childbirth-related infections. We used a combination of medical subject headings (MeSHs), to encompass any variant of infection or sepsis in relation to maternity care. We applied Boolean operators 'OR' and 'AND' to relevant keywords and word variants to capture relevant text citations (Supplementary table 1). Although our aim was to focus on bacterial infections, we did not include the terms 'bacterial' or 'microbial' in our search to reduce the risk of limiting access to all possible relevant guidelines. To ensure relevance of identified guidelines to current practice, we limited our search to the last 10 years but we did not apply any language restrictions. Additionally, we searched the Guidelines International Network (G-I-N) for any relevant guidelines not identified by our PubMed search. We also manually searched the reference lists of selected guidelines to check for possible guidelines not captured by electronic searches. Finally, we performed specific searches for relevant guidelines on the websites of the top 5 guideline producing obstetrics and gynecology international professional bodies that were most commonly identified by our searches, these were: The American College of Obstetrics and Gynecology (ACOG); Collège National des Gynécologues et Obstétriciens Français (CNGOF); The Royal Australian and New Zealand College of Obstetricians and Gynaecologists (RANZCOG); The Royal College of Obstetricians and Gynaecologists (RCOG) and The Society of Obstetricians and Gynaecologists of Canada (SOGC).

\section{Guideline selection}

Guidelines were selected in a three-stage process. First, two independent reviewers (KI \& MK) assessed titles and abstracts of identified citations and full guidelines of all selected references were obtained. Second, two independent reviewers (KI \& MK) assessed selected guidelines against pre-designed inclusion/exclusion criteria. Any disagreements between the reviewers in the first 2 stages of guidelines selection were sorted by discussion with a third reviewer (RK or LV). Guidelines were included if they provided any information about the prevention and / or management of childbirth-related bacterial infections irrespective of whether the guideline stated a recommendation or not. Because clinical guidelines should be self sufficient as a standalone guide to clinicians, a decision was made a priori that organizations or authors involved in the development of the guideline will not be contacted even if the information was considered vague or incomplete. 


\section{Data extraction \& synthesis}

Two independent reviewers (KI and MK) extracted data from selected guidelines and any discrepancy was sorted by discussion with a third reviewer (VK). Extracted information was logged in an excel spreadsheet and synthesized under the following topics: Asymptomatic bacteriuria; Group B Streptococcal infection (GBS); Preterm Premature rupture of membranes (P-PROM); Intrauterine infection / Clinical chorioamnionitis; Interventions and procedures; Maternal sepsis; Miscellaneous. Concordance was defined as absence of contradictory information between the different guidelines with regards to a specific topic, subtopic or recommendation.

\section{Assessment of risk of bias}

A bespoke checklist based on the AGREE II checklist domains for guideline reporting was used for assessing risk of bias and quality of included guidelines (Table S2) [9]. Quality assessment was then used to assess the methodological adequacies of the included guidelines and assist with the interpretation of synthesized data. Guidelines were assessed for the following domains: scope and purpose; stakeholder involvement; rigor of development, clarity of presentation; applicability and editorial independence against a set of pre-specified criteria by 2 reviewers $(\mathrm{RK} \& \mathrm{KI})$. A domain was considered fulfilled, not fulfilled or not fully fulfilled if $100 \%,<50 \%$ or 50 $99 \%$ of its criteria were deemed to be present in the assessed guideline respectively.

\section{Results}

\section{Guideline selection and guideline characteristics}

A total of 43 guidelines were selected of which 11 were excluded leaving 32 guidelines that fulfilled our inclusion criteria (Figure 1, Table 1). Of the 11 excluded guidelines, 5 were superseded by more up to date guidelines and 6 were not relevant to the review topic (supplementary Table 3).

\section{Risk of bias of included guidelines}

None of the selected guidelines fulfilled all 6 quality domains. Three $(\approx 10 \%)$ of the guidelines fulfilled 5 of the 6 domains fully while the remaining domain was partially fulfilled and were hence considered high quality guidelines. A total of 18 (56\%) of the guidelines fulfilled at least 3 - 4 of the 6 domains, while the remaining 11 (34\%) of the guidelines fulfilled 1 - 2 of domains (Figure 2). No guidelines were excluded from the systematic review for failure to fulfill the quality criteria.

\section{Synthesis of results}

We analyzed the results under the following clinical categories:

- Asymptomatic bacteriuria:

Two guidelines, produced on behalf of the United States Preventive Task Force (USPTF) [10] and SOGC [11] discussed this topic (Tables 1 \& 2). There was concordance between the two guidelines regarding universal screening for asymptomatic bacteriuria in pregnancy using mid-stream urine cultures. Both guidelines recommended treatment for a colony count $\geq 100000$ colony-forming units per milliliter, using an appropriate antibiotic. Both guidelines highlighted the moderate degree of certainty with the regards to the evidence of benefit 
in support of treatment where the evidence was graded as B-recommendation and II-2A by both guidelines respectively.

\section{- Group B Streptococcal infection (GBS)}

Nine guidelines discussed antenatal screening for GBS and / or its intrapartum antibiotic prophylaxis (Tables 1 \& 2). These guidelines were produced on behalf of RANZCOG [12], the Canadian Task Force on Preventive Health Care (CTFPHC) [13], SOGC [11], Sociedad Española de Enfermedades Infecciosas y Microbiología Clínica (SEIMC) / Sociedad Española de Medicina Familiar y Comunitaria (SEMFYC) / Sociedad Española de Ginecología y Obstetricia (SEGO) / Sociedad Española de Neonatología (SEN) / Sociedad Española de Quimioterapia (SEQ) [14], New Zealand Medical Association (NZMA) [15], American Academy of Pediatrics (AAP) [16], ACOG [17], RCOG [18] and the World Health Organization (WHO) [19]. There was lack of concordance regarding GBS screening policy between the different guidelines. A policy of routine screening of pregnant women between 35-37 weeks was recommended by CTFPHC, SOGC, SEIMC/ SEMFYC/SEGO/SEN/SEQ, AAP, CDC. In contrast, NZMA and the RCOG did not recommend universal bacteriological screening for GBS. The RCOG concluded that there was lack of clear evidence to show that routine testing for GBS would do "more good than harm". Although RANZCOG recommended routine screening between 35-37 weeks, they also stated that a risk-based approach was acceptable. Finally, the WHO guideline development group acknowledged the "considerable variations in policies regarding the screening for GBS colonization in pregnant women" and agreed that this recommendation should be implemented in line with local policy.

There was consensus between the different guidelines that the optimal method of screening is a culture-based approach using vaginal or rectal swabs. AAP also suggested that new diagnostic technologies including pigmented enrichment broths, chromogenic agars, DNA probes, and nucleic acid amplification tests might be used. Although there was agreement amongst the guidelines with regards to the use of IV penicillin, there were still some variations in the management protocol. The RCOG guideline recommended an initial dose of benzylpenicillin of $3 \mathrm{~g}$ followed by $1.5 \mathrm{~g}$ 4-hourly till delivery, compared to the NZMA recommendation of a dose of $1.2 \mathrm{~g}$ and $0.6 \mathrm{~g}$ for initial and follow-up doses respectively. Ampicillin was also deemed suitable by AAP, ACOG and RANZOG, while the RCOG, AAP and CDC suggested a cephalosporin. In case of penicillin allergy the RCOG and AAP recommended vancomycin and clindamycin respectively.

- Preterm Premature rupture of membranes (P-PROM)

This topic was covered in 5 guidelines, 2 linked guidelines produced on behalf of CNGOF) [20, 21] and one produced by each of SOGC [22], ACOG [23] and the RCOG [24] (Tables 1 \& 2). All the guidelines recommended antibiotic prophylaxis if the woman was not in labor. However there were some discrepancies in the gestational age at which antibiotics should be considered. The SOGC guideline recommended that prophylaxis should be given if $\leq 32$ weeks' gestation and considered above 32 weeks if fetal lung maturity could not be proven and/or delivery is not planned (level I-A). CNGOF used a cut off of $<37$ weeks for using antibiotic prophylaxis (Level A) while ACOG recommended a cut-off of $<34+0$ weeks of gestation. With regards to antibiotic regimens, the RCOG recommended erythromycin for 10 days, CNGOF suggested amoxicillin, 3rd generation cephalosporins, and erythromycin in monotherapy or erythromycin + amoxicillin (professional consensus) for 7 days (grade C), to be discontinued if vaginal cultures are negative, while ACOG recommended a 7-day course of therapy with a combination of intravenous ampicillin and erythromycin followed by oral amoxicillin and erythromycin. However, the regimen endorsed by SOGC was either ampicillin $2 \mathrm{~g}$ IV every 6 hours and erythromycin 250 mg IV every 6 
hours for 48 hours followed by amoxicillin 250 mg orally every 8 hours and erythromycin 333 mg orally every 8 hours for 5 days or erythromycin 250 mg orally every 6 hours for 10 days (Level I-A).

Steroids for lung maturity were recommended by both ACOG and RCOG between 24-34 weeks. ACOG and RCOG suggested that it could be considered from 23 weeks and up to 35 weeks respectively. There were some differences in the recommended gestational age for neuro-protection. ACOG recommended <32 weeks compared to the RCOG, which recommended that this would be considered from $24+0-29+6$. Regarding the place of expectant management, the RCOG and CNGOF stated that outpatient expectant management is possible while ACOG considered this option as not recommended. There were also discrepancies with regards to the management of pregnancies complicated by P-PROM who are GBS positive. The CNGOF and ACOG guidelines suggest that women can have expectant management as long as antibiotics are commenced. Although, the RCOG guideline supported expectant management, it recommended that antibiotics would only be used when in labor or if labor is planned, the guideline also recommended that delivery should be expedited if the gestational age is beyond 34 weeks.

- Intra-amniotic infections / Clinical chorioamnionitis

Three guidelines (ACOG [25], CNGOF [26] \& WHO [19]) covered this topic and there was concordance between the guidelines regarding starting combination antibiotic therapy immediately and maintaining it throughout labor (Tables 1 \& 2). The guidelines recognized the weakness of evidence to make strong recommendations regarding the duration for which antibiotics should be continued for after delivery. However, there were minor variations in the criteria for diagnosing intra-amniotic infections. According to CNGOF: a body temperature $\geq 38.0^{\circ} \mathrm{C}$ with no alternative cause identified and at least 2 of the following signs; fetal tachycardia > $160 \mathrm{bpm}$ for 10 min or longer and uterine pain or purulent cervical discharge (professional consensus). The group also added that the presence of maternal leukocytosis, in the absence of corticosteroids treatment, or increased plasma C-reactive protein should be taken into consideration despite their limited sensitivity and specificity (Evidence Level 3). ACOG used a cut off of $\geq 39^{\circ} \mathrm{C}$ for maternal temperature, on its own or $38.0-38.9^{\circ} \mathrm{C}$ together with one additional clinical risk factor. The WHO guideline acknowledged the variability and weakness of evidence regarding diagnostic criteria and did not state a recommendation

- Maternal sepsis

Our search identified 3 guidelines for the management of maternal sepsis produced on behalf of the Society for Maternal-Fetal Medicine (SMFM) / ACOG [27], RCOG [28] and the Society of Obstetric Medicine Australia and New Zealand (SOMANZ) [29]. The SMFM/ACOG guideline recommended the use of the quick sequential organ failure assessment (qSOFA) score for patient evaluation, SOMANZ recommended the obstetrically modified qSOFA for initial assessment then the obstetrically modified SOFA for a more thorough assessment. However, the RCOG advised relying on one or more of the following clinical signs suggestive of sepsis: pyrexia, hypothermia, tachycardia, tachypnoea, hypoxia, hypotension, oliguria, impaired consciousness and failure to respond to treatment. Nonetheless, the guideline highlighted that these symptoms might not be present and that they are not necessarily related to the severity. Investigations, fluid and antibiotic management were fairly consistent between the three guidelines (Tables 1 \& 2).

We identified a guideline produced on behalf of the British Infection Association [30] specific to the prevention and control of group A streptococcal (GAS) infection in acute healthcare and maternity settings in the UK. This is a 
detailed guideline addressing practical issues for the care of patients with GAS, their families and healthcare workers involved in their care and recommended antibiotic regimens for this infection.

- Pregnancy-related interventions and procedures

We identified 3 guidelines that addressed issues related to antibiotic prophylaxis in relation to some obstetricrelated procedures (Tables 1 \& 2). These were produced on behalf of the WHO [19], ACOG [31] and SOGC [32] and covered the following procedures:

Cerclage - Both ACOG and SOGC did not support the use of prophylactic antibiotics to reduce infectious morbidity following elective or emergency cerclage (SOGC - II-3).

Episiotomy - The WHO did not recommend antibiotic prophylaxis for episiotomy.

Cesarean section - There was consistency between the SOGC, ACOG and WHO with regards to antibiotic prophylaxis for cesarean section. Guidelines recommended that a single dose cephalosporin is given 15-60 minutes prior to skin incision, SOGC and ACOG recommended an additional dose of antibiotic prophylaxis if an open abdominal procedure is lengthy (>3 hours) or estimated blood loss is greater than $1500 \mathrm{ml}$. (SOGC - Grade III$\mathrm{L})$. Moreover, they advised that in patients with morbid obesity (BMI > 35), doubling the antibiotic dose may be considered (Grade III-B). Although ACOG did not recommend routine screening of pregnant women for methicillinresistant staphylococcus aureus (MRSA), the guideline suggested that consideration might be given to adding a single dose of vancomycin to the recommended antibiotic prophylaxis regimen for women undergoing caesarean delivery and known to have MRSA.

Operative vaginal delivery - The SOGC guideline concluded that the available evidence did not support the use of prophylactic antibiotics to reduce infectious morbidity following operative vaginal delivery (Grade II- 1 ). The WHO made a similar recommendation (conditional recommendation based on very low-quality evidence).

Obstetric anal sphincter injuries (OASIs) - The WHO recommended routine antibiotic prophylaxis for women who sustain OASIs. ACOG considered a single dose of antibiotic at the time of repair is reasonable (Level B). The SOGC guideline stated, "Prophylactic antibiotics may be considered for the reduction of infectious morbidity associated with repair of third and fourth degree perineal injury" (SOGC - Grade I-B).

Manual removal of the placenta (MROP) - There was some discordance between the guidelines regarding this procedure. ACOG and SOGC highlighted that there were not enough data to argue for or against antibiotic prophylaxis at the time of MROP (SOGC - Grade III). While, routine antibiotic prophylaxis was recommended by the WHO for women undergoing the procedure (strong recommendation based on very low-quality evidence).

\section{Miscellaneous}

Our search identified some guidelines that covered different topics. Two of these related to Tetanus, Diphtheria, and Pertussis Vaccination produced on behalf of the Advisory Committee on Immunization Practices (ACIP) [33] and ACOG [34] with concordant advice. The rest of the guidelines [35-41] covered a specific type of bacteria, clinical context or generic advice (Table 1). There was only one guideline identified for each of these topics hence it was not feasible to undertake analysis for concordance.

\section{Discussion}




\section{Main findings}

Our systematic review has demonstrated concordance between guidelines with regards to several aspects in the prophylaxis and treatment of bacterial infections in pregnancy. Nevertheless, there were several areas of discordance, some of which reached the extent of contradictory information as in the case of antenatal screening for GBS. Neonatal early onset GBS has been a recognized cause of neonatal morbidity and mortality for a long time $[42,43]$. The main precipitating factor for neonatal infection is maternal GBS colonization [44]. It is for this reason that several professional bodies in the USA, Spain, Australia and Canada support universal antenatal screening. However, both the NZMA and the RCOG did not support this policy. Importantly, the RCOG based their decision on the UK National Screening Committee's opinion that there is no clear evidence demonstrating benefits of routine GBS screening, lack of availability of an entirely accurate screening test and that GBS status at 35-37 weeks of gestation does not reflect GBS status at the time of delivery [18]. In stark contrast, AAP reported that the wide adoption of their recommended routine antenatal GBS screening policy resulted in an estimated $80 \%$ reduction in early onset GBS $[16,45]$. This observation was also more recently independently confirmed [46]. There was consistency between guidelines in their recommendation of antibiotic prophylaxis in P-PROM however different guidelines suggested different gestational ages for considering such prophylaxis. The discrepancies between guidelines regarding gestational ages for instigating interventions might be perceived as a minor issue. Nonetheless, there will be a significant number of women who will present with P-PROM between 32 and 37 weeks who might have had antibiotic prophylaxis based on one guideline or were denied that, and probably delivered, based on another. This is particularly relevant when considering the burden of morbidity associated with P-PROM where $25 \%$ will be complicated by clinical chorioamnionitis and up to $20 \%$ will sustain postpartum infection [ 47 , 48].

Maternal sepsis is a significant contributor to maternal mortality and considered, by WHO as "life threatening" in their newly proposed definition of the condition $[6,49]$. Therefore, one would expect that there would be consistency in its management. We identified three guidelines only that addressed maternal sepsis. Interestingly, the WHO guideline, although entitled "Prevention and treatment of maternal peripartum infections", provided no specific criteria for the diagnosis or management of sepsis. Two of the three included guidelines recommended the use of scoring tools for diagnosis; however, the RCOG suggested relying on clinical assessment. There are several tools suggested to screen for and diagnose a critically ill patient. These tools use different variables and thresholds to predict the need for specialized care or poor outcome. It is suggested that these tools are not good for the prediction or risk stratification in relation to maternal sepsis [50,51]. Moreover, there is paucity of information to enable the validation of a standardized set of investigations that can reliably diagnose maternal sepsis $[50,51]$. It is possible that these are the reasons behind which the RCOG did not recommend the use of a specific diagnostic tool. Indeed, the global maternal sepsis study (GLOSS) was set up with one of its main objectives to develop and validate identification criteria for possible severe maternal infection and maternal sepsis [52]. This issue has been highlighted by the GLOSS group, following their recent study, where they stressed the urgent need to improve early identification of maternal sepsis [5].

There were agreements between several guidelines with regards to the need for antibiotic prophylaxis in relation to several pregnancy related surgical procedures and interventions. Interestingly, there was 100\% agreement between the guidelines in not recommending antibiotic prophylaxis during OVD despite recent evidence of its benefit [53]. We appreciate that the development dates of these guidelines predates the availability of this evidence and this information might appear in future guideline updates. However, it also raises the issue of how often should 
guidelines be updated and whether this should be a continuous ongoing process or not [54]. We identified only one discrepancy in the level of evidence listed for the recommendation. Nonetheless, different professional bodies use different evidence grading systems, which can be a cause of potential confusion to the reader (Supplementary material).

\section{Comparison with existing literature}

According to the Agency for Healthcare Research and Quality, evidence-based research provides the bases for sound clinical practice guidelines and recommendations. It is possible that variations are a reflection of differences in populations, bacterial prevalence or healthcare delivery systems. Nevertheless, if the research that feeds into these guidelines comes from one source, one would expect that the recommendations generated would be similar. Our systematic review does not support this notion where several considerable variations in the interpretation of this evidence resulted in heterogeneity between the recommendations of the different guidelines for the same clinical problem. In the presence of strict criteria for the development of an evidence based guideline and, fairly, similar systems for grading the level of evidence, it would be expected that recommendations reflect the actual evidence available at the time rather than the subjective interpretation of the guideline authors. However, Nelson et al suggest that when the evidence about the effectiveness of an intervention is unclear, the decision to adopt or refute such an intervention relies upon subjective judgments about the quality of the studies in question [55]. In this situation, if there is a perception that the condition poses a relatively high risk, the guideline development group may recommend an intervention despite inadequate evidence [56]. But, Carlsen and Norheim stress that in such circumstances, it is best for guideline developers to be clear about "value judgments" [57]. Although only speculative, this might be the reason for the discrepancies in the recommendations between the guidelines. However, at least, for some of these differences, the issue of value judgment was not clearly stated, in fact, different studies were used to justify the recommended policy as in the case of GBS screening.

\section{Strengths and limitations}

The main strength of our systematic review lies in the methodology we followed in the initial selection of guidelines, the decision about their inclusion and in extracting data from these guidelines which were all done in duplicates by two independent reviewers. We also followed the AGREE II domains for assessing the quality of included guidelines. However, we are aware that despite our efforts to be inclusive, some guidelines that might have had recommendations related to the prevention and management of bacterial infections in relation to certain aspects of maternity care were not included. This applied to guidelines that are not identified on a PubMed search as in the case of the Nordic Federation of Societies of Obstetrics and Gynecology (NFOG) guidelines. It also applied to recommendations that appeared in the context of a condition specific guideline and would not have been identified by our search strategy. As an example is the RCOG guideline for the management of $3^{\text {rd }}$ and $4^{\text {th }}$ degree perineal tears where the guideline recommends the use of antibiotic prophylaxis [58]. There are probably several other examples that would fit under these categories. Nonetheless, the aim of our systematic review was not to present all the recommendations in relation to maternity-related bacterial infections but rather to assess the degree of concordance in a representative sample of international guidelines and we had to follow a pre-specified search strategy to mitigate the risk of introducing bias onto our review.

\section{Conclusion}


We appreciate that the variations we identified between guidelines do not necessarily translate into variation in care within the country where the guideline was produced by its professional body. However in many other countries clinicians rely on evidence-based guidelines produced by reputable professional societies and colleges. Adoption of different guidelines by different units, or even clinicians, in such countries can result in a high degree of variability in practice. This can have serious patient safety and medico-legal consequences. Therefore we wonder; In a world that is smaller than ever, a population that is more mobile than ever and with the existence of platforms that facilitate communication faster than ever; isn't it time to have unified international guidelines, at least for something as common as pregnancy?

\section{Declarations}

- Ethics approval and consent to participate: Not applicable

- Consent for publication: Not applicable

- Availability of data and materials: The datasets used and/or analysed during the current study are available from the corresponding author on reasonable request.

- Competing interests: The authors declare that they have no competing interests

- Funding: KI and LV are partly funded by project No. CZ.02.1.01/0.0/0.0/16_019/0000787 “Fighting INfectious Diseases - FIND“, awarded by the Ministry of Education, Youth and Sports of the Czech Republic, financed from The European Regional Development Fund. Funders were not involved in the design, analysis or the reporting of this work.

\section{- Authors' contributions}

- MK: Study selection, Data extraction, Manuscript editing and revision

- RK: Study selection, Quality assessment, Manuscript editing and revision

- LV: Study selection, Manuscript editing and revision

- VK: Data extraction and synthesis, Manuscript editing and revision

- Kl: Idea conception, Literature searches, contributed to Study selection, Data extraction and Quality assessment. Manuscript writing

All authors have read and approved the manuscript.

Acknowledgement: Not applicable

\section{References}

1. Chou D, Tunçalp Ö, Firoz T, Barreix M, Filippi V, von Dadelszen P, et al. Constructing maternal morbidity towards a standard tool to measure and monitor maternal health beyond mortality. BMC Pregnancy Childbirth. 2016;16:45. doi:10.1186/s12884-015-0789-4.

2. Chan GJ, Lee AC, Baqui AH, Tan J, Black RE. Risk of Early-Onset Neonatal Infection with Maternal Infection or Colonization: A Global Systematic Review and Meta-Analysis. PLoS Med. 2013;10:e1001502. doi:10.1371/journal.pmed.1001502.

3. Black RE, Cousens S, Johnson HL, Lawn JE, Rudan I, Bassani DG, et al. Global, regional, and national causes of child mortality in 2008: a systematic analysis. Lancet. 2010;375:1969-87. doi:10.1016/S0140- 
6736(10)60549-1.

4. Lawn JE, Cousens S, Zupan J. 4 Million neonatal deaths: When? Where? Why? Lancet. 2005;365:891-900. doi:10.1016/S0140-6736(05)71048-5.

5. Bonet M, Brizuela V, Abalos E, Cuesta C, Baguiya A, Chamillard M, et al. Frequency and management of maternal infection in health facilities in 52 countries (GLOSS): a 1-week inception cohort study. Lancet Glob Heal. 2020;8:e661-71. doi:10.1016/S2214-109X(20)30109-1.

6. Say L, Chou D, Gemmill A, Tunçalp Ö, Moller A-B, Daniels J, et al. Global causes of maternal death: a WHO systematic analysis. Lancet Glob Heal. 2014;2:e323-33. doi:10.1016/S2214-109X(14)70227-X.

7. Institute of Medicine Committee to Advise the Public Health Service on Clinical Practice G. Institute of Medicine Committee to Advise the Public Health Service on Clinical Practice, Guidelines. Washington, D.C.: National Academies Press; 1990. doi:10.17226/1626.

8. Liberati A, Altman DG, Tetzlaff J, Mulrow C, Gøtzsche PC, loannidis JPA, et al. The PRISMA statement for reporting systematic reviews and meta-analyses of studies that evaluate health care interventions: explanation and elaboration. J Clin Epidemiol. 2009;62:e1-34. doi:10.1016/j.jclinepi.2009.06.006.

9. Brouwers MC, Kho ME, Browman GP, Burgers JS, Cluzeau F, Feder G, et al. AGREE II: Advancing guideline development, reporting and evaluation in health care. J Clin Epidemiol. 2010;63:1308-11. doi:10.1016/j.jclinepi.2010.07.001.

10. Owens DK, Davidson KW, Krist AH, Barry MJ, Cabana M, Caughey AB, et al. Screening for Asymptomatic Bacteriuria in Adults. JAMA. 2019;322:1188. doi:10.1001/jama.2019.13069.

11. Allen VM, Yudin MH. No. 276-Management of Group B Streptococcal Bacteriuria in Pregnancy. J Obstet Gynaecol Canada. 2018;40:e181-6. doi:10.1016/j.jogc.2017.11.025.

12. The Royal Australian and New Zealand College of Obstetricians and Gynaecologists. Maternal Group B Streptococcus in pregnancy: screening and management. 2019.

13. Money D, Allen VM. No. 298-The Prevention of Early-Onset Neonatal Group B Streptococcal Disease. J Obstet Gynaecol Canada. 2018;40:e665-74. doi:10.1016/j.jogc.2018.05.032.

14. Cortés JIA, Domingo AA, Mir LA, Roura LC, López MC, Sastre JL, et al. Prevención de la infección perinatal por estreptococo del grupo B. Recomendaciones españolas revisadas 2012. Progresos Obstet y Ginecol. 2012;55:337-46. doi:10.1016/j.pog.2012.02.003.

15. Darlow B, Campbell N, Austin N, Chin A, Grigg C, Skidmore C, et al. The prevention of early-onset neonatal group B streptococcus infection: New Zealand Consensus Guidelines 2014. N Z Med J. 2015;128:69-76. http://www.ncbi.nlm.nih.gov/pubmed/26905989.

16. Brady MT, Bernstein HH, Byington CL, Edwards KM, Fisher MC, Glode MP, et al. Policy statement Recommendations for the prevention of perinatal group B streptococcal (GBS) disease. Pediatrics. 2011;128:611-6. doi:10.1542/peds.2011-1466.

17. Prevention of Group B Streptococcal Early-Onset Disease in Newborns: ACOG Committee Opinion Summary, Number 782. Obstet Gynecol. 2019;134:e19-40. doi:10.1097/AOG.0000000000003335.

18. Prevention of Early-onset Neonatal Group B Streptococcal Disease. BJOG An Int J Obstet Gynaecol. 2017;124:e280-305. doi:10.1111/1471-0528.14821.

19. WHO. WHO recommendations for prevention and treatment of maternal peripartum infections. 2015. https://www.who.int/reproductivehealth/publications/maternal_perinatal_health/peripartum-infectionsguidelines/en/. 
20. Schmitz T, Sentilhes L, Lorthe E, Gallot D, Madar H, Doret-Dion M, et al. Rupture prématurée des membranes avant terme: recommandations pour la pratique clinique du CNGOF - Texte court. Gynécologie Obs Fertil Sénologie. 2018;46:998-1003. doi:10.1016/j.gofs.2018.10.016.

21. Azria E. Prise en charge anténatale en cas de rupture prématurée des membranes avant la viabilité fœtale. RPC Rupture prématurée des membranes avant terme CNGOF. Gynécologie Obs Fertil Sénologie. 2018;46:1076-88. doi:10.1016/j.gofs.2018.10.023.

22. Yudin MH, van Schalkwyk J, Van Eyk N. No. 233-Antibiotic Therapy in Preterm Premature Rupture of the Membranes. J Obstet Gynaecol Canada. 2017;39:e207-12. doi:10.1016/j.jogc.2017.06.003.

23. Ehsanipoor R. The American College of Obstetricians and Gynecologists. Obstet Gynecol. 2016;128:e165e177. doi:10.1097/AOG.0000000000001712.

24. Thomson AJ. Care of Women Presenting with Suspected Preterm Prelabour Rupture of Membranes from 24+0 Weeks of Gestation: Green-top Guideline No. 73. BJOG An Int J Obstet Gynaecol. 2019;126:e152-66. doi:10.1111/1471-0528.15803.

25. Committee Opinion No. 712: Intrapartum Management of Intraamniotic Infection. Obstet Gynecol. 2017;130:e95-101. doi:10.1097/AOG.0000000000002236.

26. Beucher G, Charlier C, Cazanave C. Infection intra-utérine: diagnostic et traitement. RPC rupture prématurée des membranes avant terme CNGOF. Gynécologie Obs Fertil Sénologie. 2018;46:1054-67. doi:10.1016/j.gofs.2018.10.022.

27. Plante LA, Pacheco LD, Louis JM. SMFM Consult Series \#47: Sepsis during pregnancy and the puerperium. Am J Obstet Gynecol. 2019.

28. Royal College of Obstetricians and Gynaecologists. Bacterial Sepsis in pregnancy: Green top guideline No.64a. R Coll Obstet Gynacologists. 2012.

29. Bowyer L, Robinson HL, Barrett H, Crozier TM, Giles M, Idel I, et al. SOMANZ guidelines for the investigation and management sepsis in pregnancy. Aust New Zeal J Obstet Gynaecol. 2017;57:540-51. doi:10.1111/ajo.12646.

30. Steer JA, Lamagni T, Healy B, Morgan M, Dryden M, Rao B, et al. Guidelines for prevention and control of group A streptococcal infection in acute healthcare and maternity settings in the UK. J Infect. 2012;64:1-18. doi:10.1016/j.jinf.2011.11.001.

31. ACOG Practice Bulletin No. 199: Use of Prophylactic Antibiotics in Labor and Delivery. Obstet Gynecol. 2018;132:e103-19. doi:10.1097/AOG.0000000000002833.

32. van Schalkwyk J, Van Eyk N. No. 247-Antibiotic Prophylaxis in Obstetric Procedures. J Obstet Gynaecol Canada. 2017;39:e293-9. doi:10.1016/j.jogc.2017.06.007.

33. Sawyer M, Liang JL, Messonnier N, Clark TA. Updated recommendations for use of tetanus toxoid, reduced diphtheria toxoid, and acellular pertussis vaccine (Tdap) in pregnant women - Advisory committee on immunization practices (ACIP), 2012. Morb Mortal Wkly Rep. 2013;62:131-5. http://www.ncbi.nlm.nih.gov/pubmed/23425962.

34. Update on Immunization and Pregnancy: Tetanus, Diphtheria, and Pertussis Vaccination. Obstet Gynecol. 2017;130:668-9. doi:10.1097/AOG.0000000000002293.

35. Management of pregnant women with presumptive exposure to listeria monocytogenes. Obstet Gynecol. 2014;124:1241-4. doi:10.1097/01.aog.0000453542.64048.92. 
36. Amir LH. ABM Clinical Protocol \#4: Mastitis, Revised March 2014. Breastfeed Med. 2014;9:239-43. doi:10.1089/bfm.2014.9984.

37. Fleming N, O’Driscoll T, Becker G, Spitzer RF, Allen L, Millar D, et al. Adolescent Pregnancy Guidelines. J Obstet Gynaecol Canada. 2015;37:740-56. doi:10.1016/S1701-2163(15)30180-8.

38. Faure K, Dessein R, Vanderstichele S, Subtil D. Endométrites du post-partum. RPC infections génitales hautes CNGOF et SPILF. Gynécologie Obs Fertil Sénologie. 2019;47:442-50. doi:10.1016/j.gofs.2019.03.013.

39. Für KQ der SG, Geburtshilfe G und. Wassergeburt: Infektionsprophylaxe und Kontraindikationen. Gynakol Geburtshilfliche Rundsch. 2009;49:341-3. doi:10.1159/000301120.

40. American College of Obstetricians, Committee on Health Care for Underserved Women. Committee Opinion No. 569: oral health care during pregnancy and through the lifespan. Obstet Gynecol. 2013;122 2 Pt 1:41722.

41. Baquero-Artigao F, Mellado Peña MJ, del Rosal Rabes T, Noguera Julián A, Goncé Mellgren A, de la Calle Fernández-Miranda M, et al. Guía de la Sociedad Española de Infectología Pediátrica sobre tuberculosis en la embarazada y el recién nacido ( I ): epidemiología y diagnóstico. Tuberculosis congénita. An Pediatría. 2015;83:285.e1-285.e8. doi:10.1016/j.anpedi.2015.01.004.

42. Baker CJ. Early onset group B streptococcal disease. J Pediatr. 1978;93:124-5. doi:10.1016/S00223476(78)80623-4.

43. Baker CJ, Barrett FF, Gordon RC, Yow MD. Suppurative meningitis due to streptococci of lancefield group B: A study of 33 infants. J Pediatr. 1973;82:724-9. doi:10.1016/S0022-3476(73)80606-7.

44. Baker CJ, Barrett FF. Transmission of group B streptococci among parturient women and their neonates. J Pediatr. 1973;83:919-25. doi:10.1016/S0022-3476(73)80524-4.

45. Van Dyke MK, Phares CR, Lynfield R, Thomas AR, Arnold KE, Craig AS, et al. Evaluation of Universal Antenatal Screening for Group B Streptococcus. N Engl J Med. 2009;360:2626-36. doi:10.1056/NEJMoa0806820.

46. Rottenstreich M, Rotem R, Bergman M, Farkash R, Schimmel MS, Samueloff A, et al. Assessment of maternal GBS colonization and early-onset neonatal disease rate for term deliveries: a decade perspective. J Perinat Med. 2019;47:528-33. doi:10.1515/jpm-2018-0293.

47. Kenyon S, Boulvain M, Neilson JP. Antibiotics for preterm rupture of membranes. Cochrane Database Syst Rev. 2013;2013. doi:10.1002/14651858.CD001058.pub3.

48. Beydoun SN, Yasin SY. Premature rupture of the membranes before 28 weeks: Conservative management. Am J Obstet Gynecol. 1986;155:471-9. doi:10.1016/0002-9378(86)90257-7.

49. WHO. Statement on Maternal Sepsis Sepsis. Who. 2017;:1-4. http://apps.who.int/iris/bitstream/10665/254608/1/WHO-RHR-17.02-eng.pdf.

50. Edwards SE, Grobman WA, Lappen JR, Winter C, Fox R, Lenguerrand E, et al. Modified obstetric early warning scoring systems (MOEWS): validating the diagnostic performance for severe sepsis in women with chorioamnionitis. Am J Obstet Gynecol. 2015;212:536.e1-536.e8. doi:10.1016/j.ajog.2014.11.007.

51. Aarvold ABR, Ryan HM, Magee LA, Von Dadelszen P, Fjell C, Walley KR. Multiple Organ Dysfunction Score Is Superior to the Obstetric-Specific Sepsis in Obstetrics Score in Predicting Mortality in Septic Obstetric Patients. Crit Care Med. 2017.

52. Bonet M, Souza JP, Abalos E, Fawole B, Knight M, Kouanda S, et al. The global maternal sepsis study and awareness campaign (GLOSS): study protocol. Reprod Health. 2018;15:16. doi:10.1186/s12978-017-0437-8. 
53. Knight M, Chiocchia V, Partlett C, Rivero-Arias O, Hua X, Hinshaw K, et al. Prophylactic antibiotics in the prevention of infection after operative vaginal delivery (ANODE): a multicentre randomised controlled trial. Lancet. 2019;393:2395-403. doi:10.1016/S0140-6736(19)30773-1.

54. Shekelle P, Eccles MP, Grimshaw JM, Woolf SH. When should clinical guidelines be updated? BMJ. 2001;323:155-7. doi:10.1136/bmj.323.7305.155.

55. Nelson HD, Tyne K, Naik A, Bougatsos C, Chan BK, Humphrey L. Screening for breast cancer: An update for the U.S. Preventive Services Task Force. Annals of Internal Medicine. 2009;151:727-37.

56. Cuervo LG, Clarke M. Balancing benefits and harms in health care. British Medical Journal. 2003;327:65-6.

57. Carlsen B, Norheim OF. "What lies beneath it all?" - An interview study of GPs' attitudes to the use of guidelines. BMC Health Serv Res. 2008;8.

58. Fernando R, Sultan A, Freeman R, Williams A, Adams E. The Management of Third- and Fourth-Degree Perineal Tears (Green-Top Guideline No. 29). 2015.

https://www.rcog.org.uk/globalassets/documents/guidelines/gtg-29.pdf.

\section{Tables}

Table 1: Included guidelines sorted by topic covered 


\begin{tabular}{|c|c|c|c|c|c|}
\hline Reference & $\begin{array}{l}\text { Region / } \\
\text { Country }\end{array}$ & Year & Organization & Title & Topic \\
\hline \multirow[t]{3}{*}{10} & USA & 2019 & USPSTF & $\begin{array}{l}\text { Screening for } \\
\text { Asymptomatic } \\
\text { Bacteriuria in Adults }\end{array}$ & $\begin{array}{l}\text { Asymptomatic } \\
\text { bacteriuria }\end{array}$ \\
\hline & & & & $\begin{array}{l}\text { US Preventive } \\
\text { Services Task Force }\end{array}$ & \\
\hline & & & & $\begin{array}{l}\text { Recommendation } \\
\text { Statement }\end{array}$ & \\
\hline 11 & Canada & 2018 & SOGC & $\begin{array}{l}\text { No. 276- } \\
\text { Management of } \\
\text { Group B } \\
\text { Streptococcal } \\
\text { Bacteriuria in } \\
\text { Pregnancy }\end{array}$ & $\begin{array}{l}\text { Asymptomatic } \\
\text { bacteriuria / } \\
\text { GBS }\end{array}$ \\
\hline 12 & $\begin{array}{l}\text { Australia } \\
\text { / New } \\
\text { Zealand }\end{array}$ & 2019 & RANZCOG & $\begin{array}{l}\text { Maternal Group B } \\
\text { Streptococcus in } \\
\text { pregnancy: } \\
\text { Screening and } \\
\text { management }\end{array}$ & GBS \\
\hline 13 & Canada & 2018 & CTFPHC & $\begin{array}{l}\text { The Prevention of } \\
\text { Early-Onset Neonatal } \\
\text { Group B } \\
\text { Streptococcal } \\
\text { Disease }\end{array}$ & GBS \\
\hline 14 & Spain & 2012 & SEIMC/SEMFYC/SEGO/SEN/SEQ & $\begin{array}{l}\text { Prevención de la } \\
\text { infección perinatal } \\
\text { por estreptococo del } \\
\text { grupo B. } \\
\text { Recomendaciones } \\
\text { españolas revisadas } \\
2012\end{array}$ & GBS \\
\hline 15 & $\begin{array}{l}\text { New } \\
\text { Zealand }\end{array}$ & 2014 & NZMA & $\begin{array}{l}\text { The prevention of } \\
\text { early-onset neonatal } \\
\text { group B } \\
\text { streptococcus } \\
\text { infection: New } \\
\text { Zealand Consensus } \\
\text { Guidelines 2014. }\end{array}$ & GBS \\
\hline 16 & USA & 2011 & AAP & $\begin{array}{l}\text { Policy Statement- } \\
\text { Recommendations } \\
\text { for the Prevention } \\
\text { of Perinatal Group B } \\
\text { Streptococcal (GBS) } \\
\text { Disease }\end{array}$ & GBS \\
\hline 17 & USA & 2019 & ACOG & $\begin{array}{l}\text { Prevention of Early- } \\
\text { Onset Group B } \\
\text { Streptococcal } \\
\text { Disease in } \\
\text { Newborns. ACOG } \\
\text { Committee opinion } \\
\text { No. } 782\end{array}$ & GBS \\
\hline 18 & UK & 2017 & RCOG & Prevention of Early- & GBS \\
\hline
\end{tabular}

Page 15/21 


\begin{tabular}{|c|c|c|c|c|c|}
\hline & & & & $\begin{array}{l}\text { onset Neonatal } \\
\text { Group B } \\
\text { Streptococcal } \\
\text { Disease }\end{array}$ & \\
\hline 19 & Global & 2015 & WHO & $\begin{array}{l}\text { WHO } \\
\text { recommendations } \\
\text { for prevention and } \\
\text { treatment of } \\
\text { maternal peripartum } \\
\text { infections }\end{array}$ & $\begin{array}{l}\text { GBS / } \\
\text { Intra-amniotic } \\
\text { infection / } \\
\text { Procedures \& } \\
\text { interventions }\end{array}$ \\
\hline 20 & France & 2018 & CNGOF & $\begin{array}{l}\text { Antenatal } \\
\text { management in case } \\
\text { of preterm } \\
\text { premature rupture of } \\
\text { membranes before } \\
\text { fetal viability: } \\
\text { CNGOF Preterm } \\
\text { Premature Rupture } \\
\text { of Membranes } \\
\text { Guidelines }\end{array}$ & P-PROM \\
\hline 21 & France & 2018 & CNGOF & $\begin{array}{l}\text { Preterm premature } \\
\text { rupture of } \\
\text { membranes: CNGOF } \\
\text { Guidelines for } \\
\text { clinical practice - } \\
\text { Short version }\end{array}$ & P-PROM \\
\hline 22 & Canada & 2017 & SOGC & $\begin{array}{l}\text { No. 233-Antibiotic } \\
\text { Therapy in Preterm } \\
\text { Premature Rupture } \\
\text { of the Membranes }\end{array}$ & P-PROM \\
\hline 23 & USA & 2016 & ACOG & $\begin{array}{l}\text { ACOG Practice } \\
\text { bulletin 172: } \\
\text { Premature Rupture } \\
\text { of Membranes }\end{array}$ & P-PROM \\
\hline 24 & UK & 2019 & RCOG & $\begin{array}{l}\text { Care of Women } \\
\text { Presenting with } \\
\text { Suspected Preterm } \\
\text { Prelabour Rupture of } \\
\text { Membranes from } \\
\text { 24+0 Weeks of } \\
\text { Gestation }\end{array}$ & P-PROM \\
\hline 25 & USA & 2017 & ACOG & $\begin{array}{l}\text { Intrapartum } \\
\text { Management of } \\
\text { Intraamniotic } \\
\text { Infection }\end{array}$ & $\begin{array}{l}\text { Intra-amniotic } \\
\text { infection }\end{array}$ \\
\hline 26 & France & 2018 & CNGOF & $\begin{array}{l}\text { Diagnosis and } \\
\text { management of } \\
\text { intra-uterine } \\
\text { infection: CNGOF } \\
\text { Preterm Premature } \\
\text { Rupture of } \\
\text { Membranes } \\
\text { Guidelines }\end{array}$ & $\begin{array}{l}\text { Intra-amniotic } \\
\text { infection }\end{array}$ \\
\hline 27 & USA & 2019 & SMFM/ACOG & $\begin{array}{l}\text { SMFM Consult } \\
\text { Series \#47: Sepsis }\end{array}$ & $\begin{array}{l}\text { Maternal } \\
\text { sepsis }\end{array}$ \\
\hline
\end{tabular}

Page 16/21 


\begin{tabular}{|c|c|c|c|c|c|}
\hline & & & & $\begin{array}{l}\text { during pregnancy } \\
\text { and the puerperium }\end{array}$ & \\
\hline 28 & UK & 2012 & $\mathrm{RCOG}$ & $\begin{array}{l}\text { Bacterial Sepsis in } \\
\text { Pregnancy }\end{array}$ & $\begin{array}{l}\text { Maternal } \\
\text { sepsis }\end{array}$ \\
\hline 29 & $\begin{array}{l}\text { Australia } \\
\text { \& New } \\
\text { Zealand }\end{array}$ & 2017 & SOMANZ & $\begin{array}{l}\text { SOMANZ guidelines } \\
\text { for the investigation } \\
\text { and management } \\
\text { sepsis in pregnancy }\end{array}$ & $\begin{array}{l}\text { Maternal } \\
\text { sepsis }\end{array}$ \\
\hline 30 & UK & 2012 & British Infection Association & $\begin{array}{l}\text { Guidelines for } \\
\text { prevention and } \\
\text { control of group A } \\
\text { streptococcal } \\
\text { infection in acute } \\
\text { healthcare and } \\
\text { maternity settings in } \\
\text { the UK }\end{array}$ & $\begin{array}{l}\text { Maternal } \\
\text { sepsis }\end{array}$ \\
\hline 31 & USA & 2018 & ACOG & $\begin{array}{l}\text { Use of Prophylactic } \\
\text { Antibiotics in Labor } \\
\text { and Delivery }\end{array}$ & $\begin{array}{l}\text { Procedures } \\
\text { and } \\
\text { interventions }\end{array}$ \\
\hline 32 & Canada & 2017 & SOGC & $\begin{array}{l}\text { No. } 247 \text {-Antibiotic } \\
\text { Prophylaxis in } \\
\text { Obstetric Procedures }\end{array}$ & $\begin{array}{l}\text { Procedures } \\
\text { and } \\
\text { interventions }\end{array}$ \\
\hline 33 & USA & 2013 & ACIP & $\begin{array}{l}\text { Updated } \\
\text { Recommendations } \\
\text { for Use of Tetanus } \\
\text { Toxoid, Reduced } \\
\text { Diphtheria Toxoid, } \\
\text { and Acellular } \\
\text { Pertussis Vaccine } \\
\text { (Tdap) in Pregnant } \\
\text { Women - Advisory } \\
\text { Committee on } \\
\text { Immunization } \\
\text { Practices (ACIP), } \\
2012\end{array}$ & Miscellaneous \\
\hline 34 & USA & 2017 & ACOG & $\begin{array}{l}\text { Committee Opinion } \\
\text { No. } 718 \text { Summary: } \\
\text { Update on } \\
\text { Immunization and } \\
\text { Pregnancy Tetanus, } \\
\text { Diphtheria, and } \\
\text { Pertussis } \\
\text { Vaccination }\end{array}$ & Miscellaneous \\
\hline 35 & USA & 2014 & ACOG & $\begin{array}{l}\text { Committee Opinion } \\
\text { No. 614: } \\
\text { Management of } \\
\text { Pregnant Women } \\
\text { With Presumptive } \\
\text { Exposure to Listeria } \\
\text { monocytogenes }\end{array}$ & Miscellaneous \\
\hline 36 & USA & 2014 & $\begin{array}{l}\text { Academy of Breastfeeding } \\
\text { Medicine }\end{array}$ & $\begin{array}{l}\text { ABM Clinical } \\
\text { Protocol \#4: } \\
\text { Mastitis, Revised } \\
\text { March } 2014\end{array}$ & Miscellaneous \\
\hline 37 & Canada & 2015 & SOGC & Adolescent & Miscellaneous \\
\hline
\end{tabular}




\begin{tabular}{|c|c|c|c|c|c|}
\hline & & & & $\begin{array}{l}\text { Pregnancy } \\
\text { Guidelines }\end{array}$ & \\
\hline 38 & France & 2019 & CNGOG / SPILF & $\begin{array}{l}\text { Postpartum } \\
\text { endometritis: CNGOF } \\
\text { and SPILF Pelvic } \\
\text { Inflammatory } \\
\text { Diseases Guidelines }\end{array}$ & Miscellaneous \\
\hline 39 & Germany & 2009 & $\begin{array}{l}\text { Kommission Qualitätssicherung } \\
\text { der Schweizerischen Gesellschaft } \\
\text { für } \\
\text { Gynäkologie und Geburtshilfe }\end{array}$ & $\begin{array}{l}\text { Wassergeburt: } \\
\text { Infektionsprophylaxe } \\
\text { und } \\
\text { Kontraindikationen }\end{array}$ & Miscellaneous \\
\hline 40 & USA & 2013 & ACOG & $\begin{array}{l}\text { Oral Health Care } \\
\text { During Pregnancy } \\
\text { and Through the } \\
\text { Lifespan }\end{array}$ & Miscellaneous \\
\hline 41 & Spain & 2015 & $\begin{array}{l}\text { Spanish Association of } \\
\text { Paediatrics }\end{array}$ & $\begin{array}{l}\text { Spanish Society for } \\
\text { Pediatric Infectious } \\
\text { Diseases } \\
\text { guidelines on } \\
\text { tuberculosis in } \\
\text { pregnant women } \\
\text { and } \\
\text { neonates (ii): } \\
\text { Prophylaxis and } \\
\text { treatment }\end{array}$ & Miscellaneous \\
\hline
\end{tabular}

Table 2: Concordance between guidelines for different pregnancy-related topics 


\begin{tabular}{|lll|}
\hline Topic & Concordance & Organization \\
\hline $\begin{array}{l}\text { Screening for and treatment of Asymptomatic } \\
\text { bacteriuria }\end{array}$ & $\square$ & USPTF, SOGC \\
\hline Screening for GBS & $\square$ & $\begin{array}{l}\text { CTFPHC, SOGC,SEIMC/SEGO/SEN/SEQ, } \\
\text { AAP, CDC, NZMA, RCOG, WHO }\end{array}$ \\
\hline Method of GBS diagnosis & $\square$ & \\
\hline Choice of antibiotic prophylaxis for GBS & $\square$ & ACOG, CNGOF, RCOG \\
\hline GBS with PPROM & $\square$ & ACOG, CNGOF, SOGC, RCOG \\
\hline Intrapartum antibiotic prophylaxis for P-PROM & $\square$ & ACOG, RCOG \\
\hline $\begin{array}{l}\text { Gestational age for use of steroids for lung } \\
\text { maturity in PPROM }\end{array}$ & $\square$ & ACOG, RCOG \\
\hline $\begin{array}{l}\text { Gestational age for use of magnesium sulfate for } \\
\text { neuroprotection in PPROM }\end{array}$ & $\square$ & ACOG, CNGOF, WHO \\
\hline $\begin{array}{l}\text { Intra-amniotic infection diagnosis } \\
\text { Intra-amniotic infection management }\end{array}$ & $\square$ & \\
\hline Maternal sepsis diagnosis & $\square$ & ACOG/SMFM, RCOG, SOMANZ \\
\hline Maternal sepsis management & $\square$ & \\
\hline $\begin{array}{l}\text { No need for antibiotic prophylaxis with elective } \\
\text { cerclage }\end{array}$ & $\square$ & ACOG, SOGC \\
\hline Antibiotic prophylaxis at CS & $\square$ & ACOG, SOGC, WHO \\
\hline No need for antibiotic prophylaxis with OVD & $\square$ & SOGC, WHO \\
\hline Antibiotic prophylaxis for OASIs & $\square$ & ACOG, SOGC, WHO \\
\hline
\end{tabular}

\section{Figures}




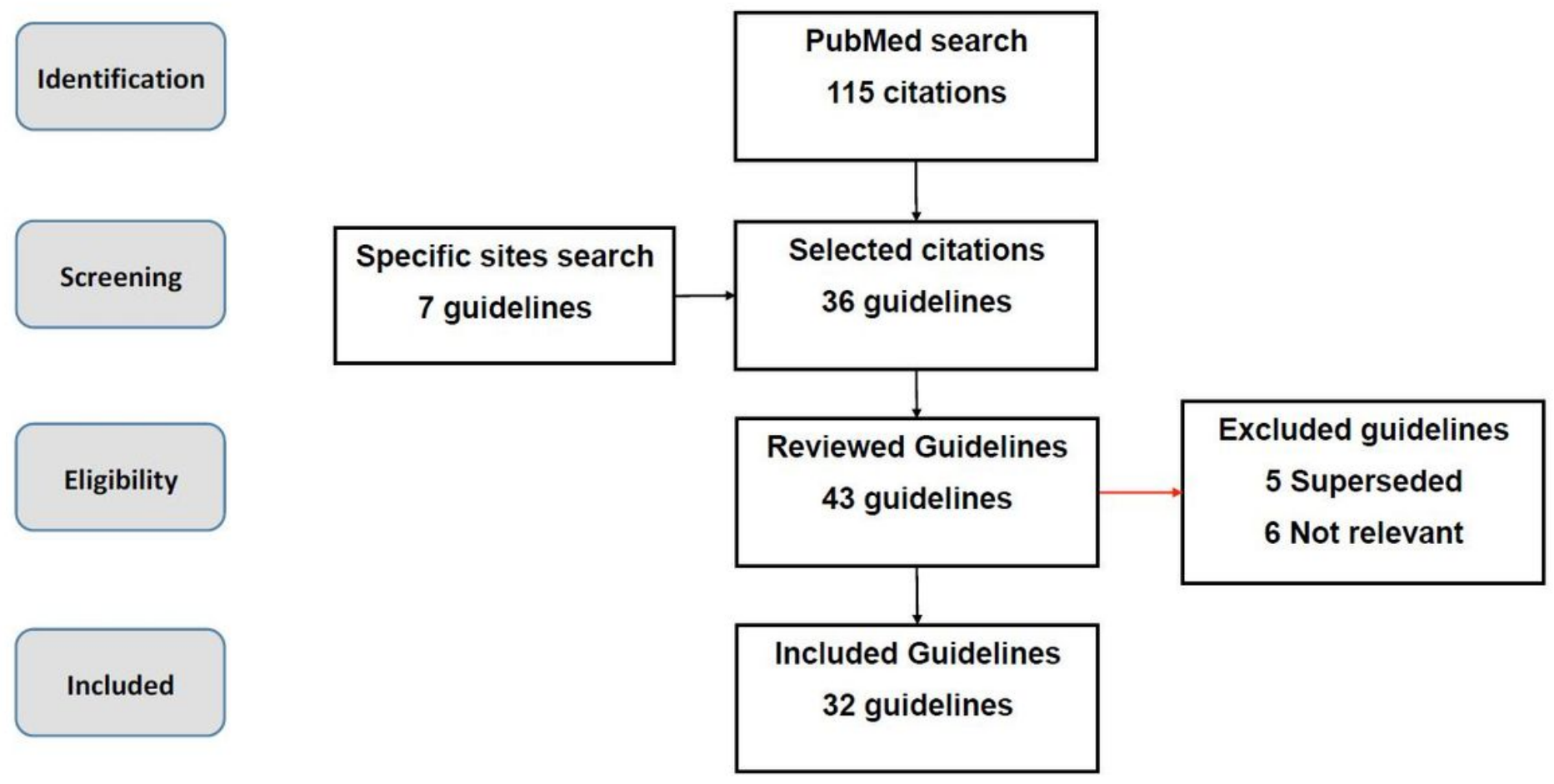

Figure 1

PRISMA flowchart of guideline selection and inclusion.

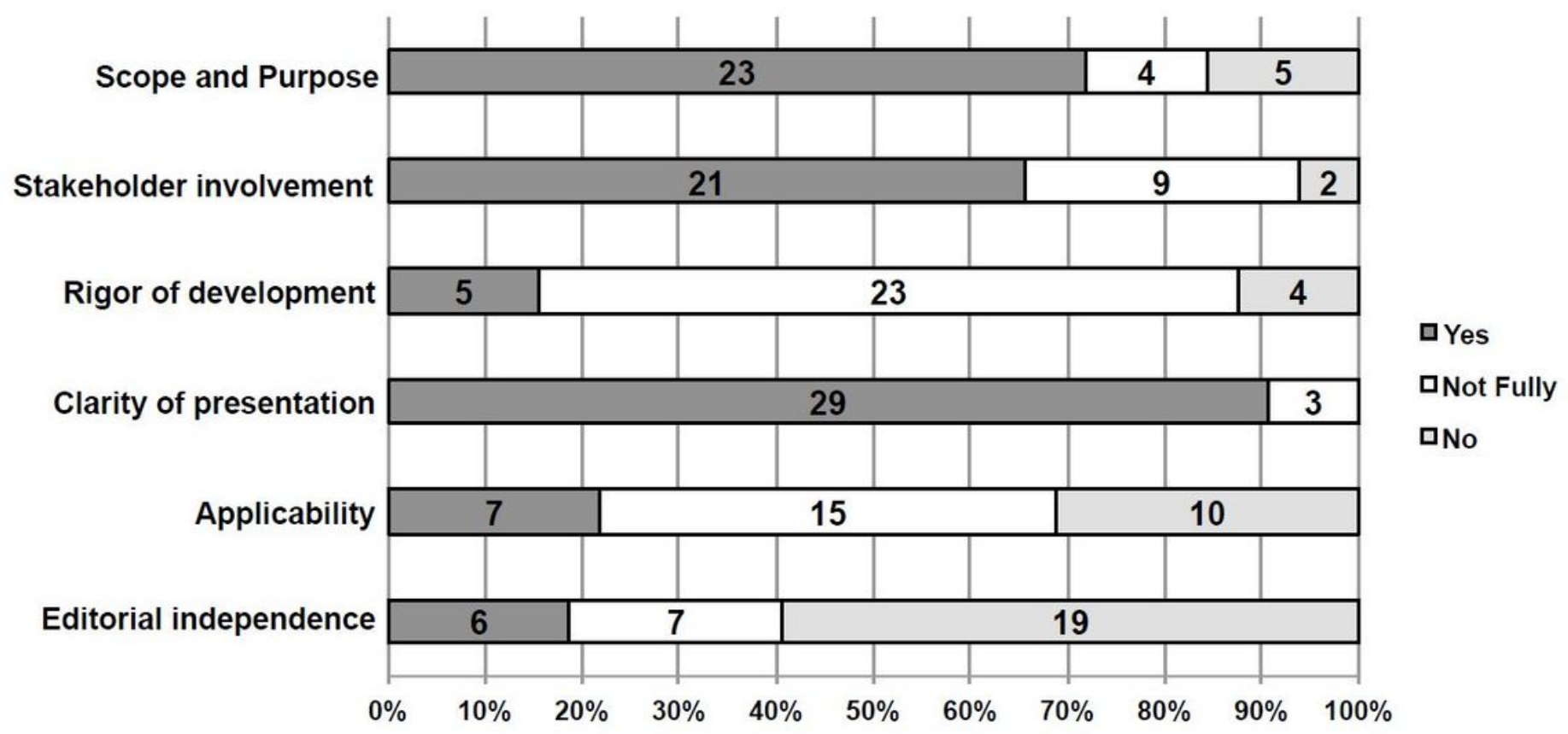

Figure 2

Summary of quality assessment of included guidelines. 


\section{Supplementary Files}

This is a list of supplementary files associated with this preprint. Click to download.

- MaternalbacterialinfectionsSupplementarytablesfinal.docx 